\title{
Landslide stability assessment along Panchkula-Morni road, Nahan salient, NW Himalaya, India
}

\author{
Jaspreet Singh ${ }^{1,2}$ and Mahesh Thakur ${ }^{1, *}$ \\ ${ }^{1}$ Centre of Advanced Study in Geology, Panjab University, Chandigarh 160 014, India. \\ ${ }^{2}$ Department of Earth Sciences, Indian Institute of Technology, Roorkee, Uttarakhand 247 667, India. \\ *Corresponding author. e-mail: mahesh09@gmail.com
}

MS received 19 September 2018; revised 21 February 2019; accepted 26 February 2019; published online 4 June 2019

We report the slope stability analysis of three vulnerable sites (S1, S2 and S3) within the lower Siwalik along the Panchkula-Morni road section in the Nahan salient, north-western Himalaya. Kinematic analysis of joint data was conducted to understand the different modes of failure. Rock mass classification techniques like rock mass rating, slope mass rating (SMR) and continuous SMR were used for stability classification and the factor of safety was calculated using stability charts. At site S1, the instability is controlled by the orientation of the discontinuity joint J1 which is parallel to the bedding and at site $\mathrm{S} 2$, the slope fails due to the wedge. The Umri landslide site S3 is the product of a damage zone by the normal faults which intersect at joint J3; a wedge is formed which falls in the critical zone. The damage zone in the Umri landslide greatly affects the porosity and permeability of the rockmass and acts as a pathway for the percolation of water during rainfall which reduces effective stress. The slope failures are tectonically controlled results due to the high slope angles, structural discontinuities like joints and faults and structural damage zones associated with the faults.

Keywords. Umri landslide; joint; RMR; SMR; CSMR; kinematic analysis; factor of safety and tectonics.

\section{Introduction}

Landslides are natural disasters that affect the hilly areas and are mainly triggered by earthquakes, rainfall and other structural failures under the influence of gravity. Himalaya is very prone to natural disasters like earthquakes, extreme rainfall and landslides (Paul et al. 2000; Bali et al. 2009; Ray et al. 2009; Kothyari et al. 2012; Bhambri et al. 2017; Kumar et al. 2017a, b; Sah et al. 2018). The ongoing convergence along the Indian-Eurasian plate resulting in a $3-28 \mathrm{~mm} / \mathrm{yr}$ movement along the main thrust zones of the different segments of the Himalayas (Larson et al. 1999; Avouac 2003; Bettinelli et al. 2006; Jade et al. 2017) has been building the highest mountain range in the world and continuously transforming in terms of the geomorphology and tectonics of the region. Tourists, pilgrims and local people are the most affected by the landslides that pose a great risk to life and property (Bhambri et al. 2017; Kumar et al. 2017a, b; Siddique et al. 2017). The development work in the Himalaya like roads, rail network and infrastructure projects have enhanced the landslide in many ways by affecting the natural flow of water, increasing the load, erosion, weathering and changing the slope angle of natural slopes (Umrao et al. 2011). Moreover, the failure in stratified rocks is dominantly controlled by the dip and the mechanical properties of the bedding planes 
and results in planar, circular or non-circular failures depending upon the conditions (Bhambri et al. 2017; Kumar et al. 2017a,b; Singh et al. 2017). The presence of faults, folds, shear zones and other tectonic structures are commonly associated with rock slope failures (Agliardi et al. 2001; Jackson 2002; Ambrosi and Crosta 2006). Lee and Nguyen (2005) found that the distance from the tectonic fracture largely controls the instability of the slope. Folded or inclined bedding provides the surface for failure to occur while faults facilitate the development of lateral or rear-release surfaces (Brideau and Stead 2009). The intersection of faults results in the zone of low rock quality designation (RQD) value due to the intense jointing or other type of fractures (Brideau and Stead 2009). The rock mass damage associated with the faults greatly affects the porosity and permeability of the rock mass (Shipton and Cowie 2001, 2003; Bergbauer and Pollard 2004).

Stead and Wolter (2015) mentioned investigating slope stability, to first consider the influence of major structures such as faults, shear zones and persistence of bedding planes and then incorporated the mechanics of joints. The slope instability is often governed by fault planes because it acts as a sliding or release surface and is also associated with the steepening of the beds due to drag-folding over the fault plane (Stead and Wolter 2015). Furthermore, the increase in seismic stress due to earthquakes overcomes the strength of the underlying rocks or soil causing failure in slopes (Newmark 1965; Meunier et al. 2007). Slope mass rating (SMR) is a commonly used parameter to understand the slopes (Pradhan et al. 2011). Sarkar et al. (2016) used continuous SMR (CSMR) and kinematic analysis techniques for a detailed investigation of slopes along National Highway-22, Himachal Pradesh. The Himalayan rocks contain several sets of discontinuity planes and the nonscientific slope cuts the blocks of different sizes formed due to multiple sets of discontinuities which are highly vulnerable to sliding or falling. The study area is close to Nahan thrust, where the rocks have suffered deformation and damage due to repeated earthquake activity in its vicinity (Nakata 1989). The changing slope face direction along the road naturally, largely influences the stability along the different joint sets, so it is of prime importance to investigate vulnerable slopes. During a field investigation, three unstable slopes at sites S1, S2 and S3 located in the lower Siwalik were found along the Panchkula-Morni road (figures 1 and 2). Detailed geological and geotechnical investigation of the slopes was carried out for stability assessment. Different rock mass and slope mass characterisation techniques like rock mass rating (RMR), SMR and CSMR were implemented for stability classification along with the kinematic analysis. Stability along all three slopes is structurally controlled due to the different joint sets and, particularly, at site S3, the normal fault within the slope favours the kinematic release of the rock blocks.

\section{Geology and tectonics of the area}

Morni is one of the famous tourist hill stations in Panchkula district, Haryana. The study area lies in the Panchkula district of Haryana, India (figure 1) where the rocks belong to the lower Siwalik formation of the Siwalik group in the Himalayan foreland basin (Kumar and Tandon 1985; Thakur et al. 2010) (figure 2). The Siwaliks are formed by the accumulation of molasses deposits in the Himalaya foreland basin and are late deformed by the tectonic events (Lave and Avouac 2000; Kothyari et al. 2010; Jayangondaperumal et al. 2018). The lower Siwalik rocks are dominantly composed of sandstone and are mainly medium to fine-grained and these sandstones are hard and compactly interbedded with clay and mudstones (Krishnan 2009). The exposed sandstones of the lower Siwalik along the Panchkula-Morni road cut slope contain multiple joint sets. The stratigraphy of the Siwalik group is shown in table 1 . In the south of the study area, Nahan thrust (NT) marks the boundary between the lower Siwalik and upper Siwalik rocks and on the west, an active strike-slip fault (Kumar and Tandon 1985; Arora and Malik 2017). Further north, it is bounded by the Eocene age marine shales of the Subathu formation. The Medlicott Wadia thrust (MWT) marks the boundary between Subathu and the lower Siwalik rocks (Kumar and Tandon 1985; Thakur et al. 2010) as shown in figure 2.

\section{Neotectonic movements in the area}

The thrust fault between the lower Tertiary and the Siwaliks was designated the main boundary fault (MBF) (Medlicott 1864; Pilgrim and West 1928; Auden 1934) and Thakur et al. (2010) assigned a new name to the MBF as the MWT. The MWT is an important fault of regional dimension and is 


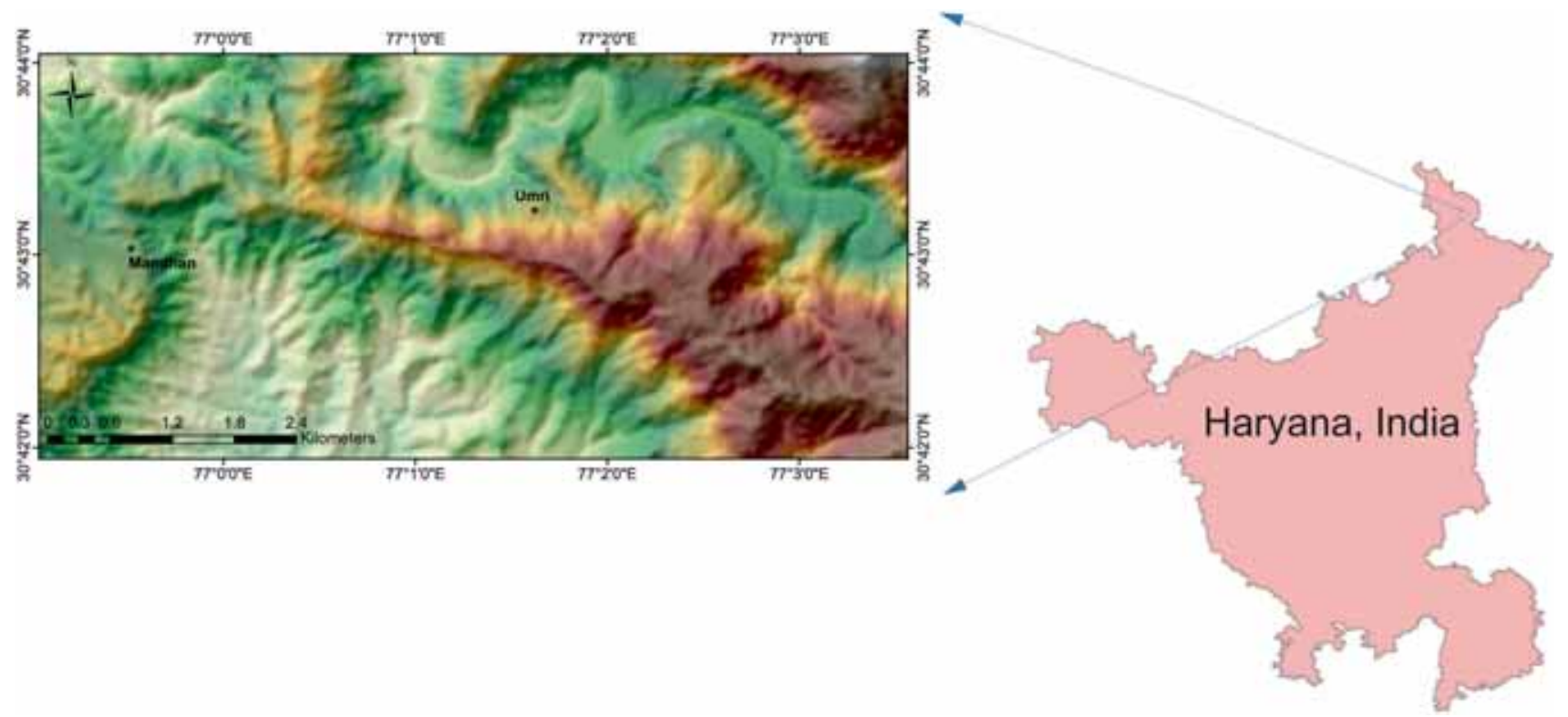

Figure 1. Location map: image shows the location of Haryana and a Hillshade view of the study area in the Morni region.

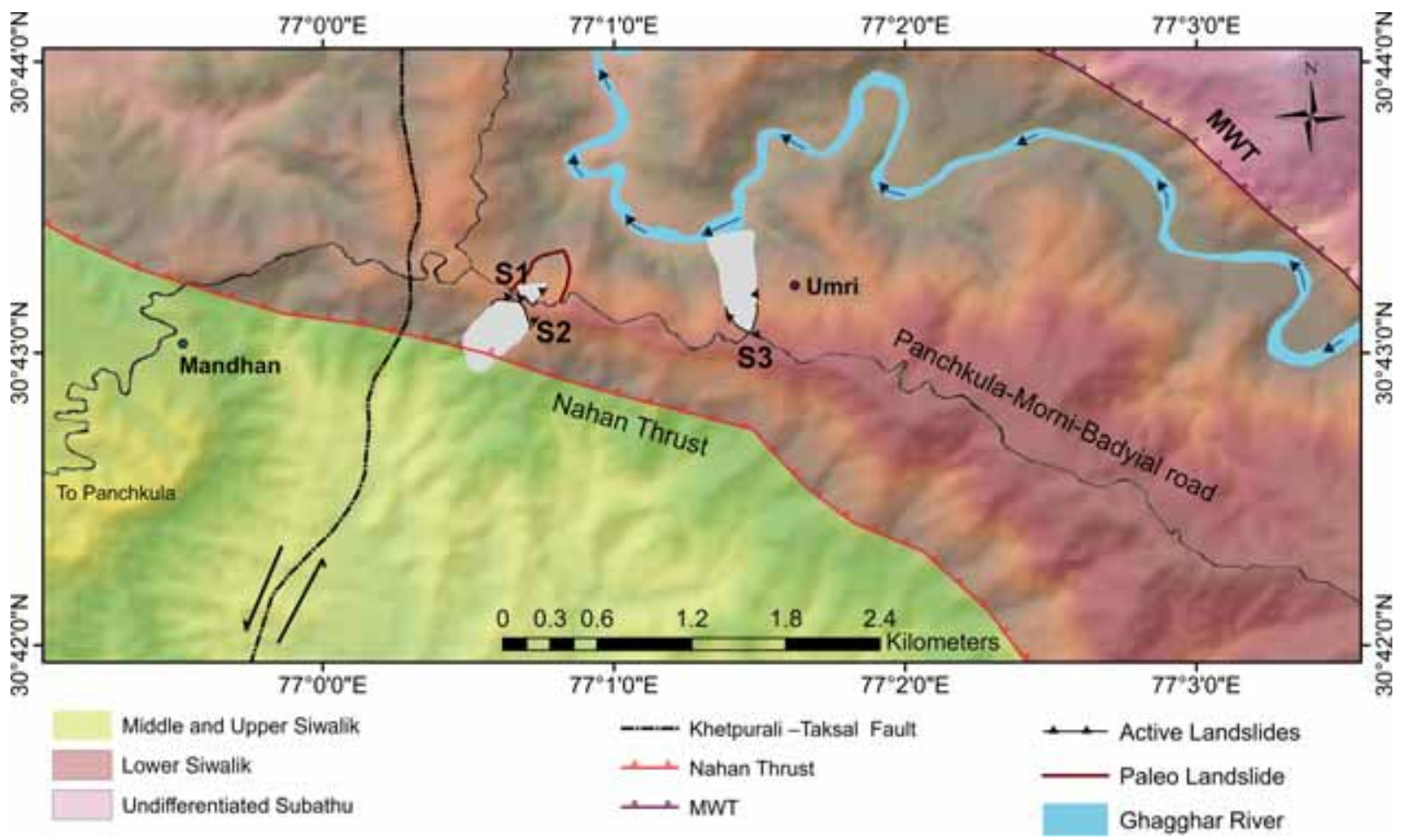

Figure 2. Geological map of the study area. Three unstable slopes (S1, S2 and S3) are marked in white colour on the map.

active in some regions between the MBT and the HFT along its strike length of $\sim 700 \mathrm{~km}$ (Thakur et al. 2010). Nakata (1989) demonstrated the active faulting along the Nahan thrust, showing a 250 $\mathrm{m}$ right-lateral displacement of the Koshallia river channel. Malik and Nakata (2003) identified the extension of this Nahan fault trending along the NNW-SSE and spanning a distance of about 20 $\mathrm{km}$. They named this active fault, the Taksal fault, which formed a part of the Nahan thrust system. A strike slip fault was first reported by Kumar and Tandon (1985) in the Khetpurali area, based on an offset of geological formation in this area. The active signatures of the Ketpurali-Taksal fault were like a sag pond, an offset of streams and many more features as reported by Arora and Malik (2017). Compressional movement along the Nahan thrust at the Kalawar gallery with a slip vector 
Table 1. Stratigraphic succession of the Siwaliks (Krishnan 2009).

\begin{tabular}{ll}
\hline Units & Lithology \\
\hline Upper Siwaliks & Course boulder conglomerates with red and orange clay. \\
& Sandstone, clay and conglomerate \\
Middle Siwaliks & Massive sandstone with minor conglomerate. \\
& Medium-coarse grained sandstone, locally thick \\
& conglomerates \\
Line-medium grained sandstone, calcareous cement and & maroon, chocolate clay. \\
& Red claystone with intercalations of medium to fine-grained \\
& sandstone
\end{tabular}

has a magnitude of $10 \mathrm{~mm} / \mathrm{yr}$ and is orientated in a direction $132^{\circ} \mathrm{E}$ (Sinvhal et al. 1973). Evidence of palaeoearthquakes is shown by Malik and Mathew (2005) from trench investigations across the active Pinjore Garden fault in Pinjore Dun. Two events of reactivation of the Nalagarh thrust in the Quaternary west of the study area were reported by Philip et al. (2014). The trenches excavated across HFT for palaeoseismological studies between Chandigarh and Kala Amb, Himachal Pradesh ruptured and generated two major earthquakes ( $M \sim 7$ or 8 ) during the last 2000 yr (Malik et al. 2003; Kumar et al. 2006). The study area is tectonically active, bounded by active faults, and a local normal fault is also found at site S3 (Umri landslide) as shown in figure 2 .

\section{GIS-based observations and interpretations}

\subsection{Slope and other aspects of the study area}

Topography features such as elevation and slope angle, etc. largely influence the geomorphology of the region, which, in turn, limits the extent of landslides both temporally and spatially (Chauhana et al. 2010). The Cartosat digital elevation model (DEM) data $(30 \mathrm{~m})$ is downloaded from the Bhuwan website (www.bhuvan.nrsc.gov.in) and is used to analyse the slope and other aspects of the study area using ArcGIS 10.3 software.

A high slope angle may cause an instability in the rock mass as it affects the drainage of the area. In many areas due to steeper slopes, the bed's daylights can result in the failure of the slope; therefore, it is important to understand the spatial distribution of the slope angle, which is prepared from the DEM data. The slope angle in the study area varies from $0^{\circ}$ to $70^{\circ}$ as shown in figure 3. At site $\mathrm{S} 1$, the slope angle varies from $25^{\circ}$ to $34^{\circ}$ and the slope dip towards the north. At site $\mathrm{S} 2$, the south dipping slope has a high slope angle of $44-73^{\circ}$ along the Nahan thrust which is a contact between the Nahan formation sandstone and the upper Siwalik (figure 3). A high slope angle in the south facing slope along the Nahan thrust is due to the comparatively resistant and indurated sandstones of the lower Siwalik rocks overriding the upper Siwalik sequence of mudstone and clays. This is the prime reason for the high slope angle and is one of the main reasons of the resulting instability of the slope in the region. The slope angle at site S3 (Umri landslide) lies between $25^{\circ}$ and $50^{\circ}$ and it dips towards the north. The slope angle is low at site S3, but the slope is unstable pointing towards the fact that this may result due to unfavourable structural discontinuities.

Aspect is another important parameter; it defines the dip direction of the slope. The southfacing slopes are humid and lack vegetation, whereas the north-facing slopes experience more orographic rainfall and are relatively cool and have high moisture content (Chauhana et al. 2010). The aspect map is prepared from the DEM data and divided into nine aspect categories (Mathew et al. 2005) listed as (a) north, (b) north-east, (c) east, (d) south-east, (e) south, (f) south-west, (g) west, (h) north-west and (i) flat. At sites S1 and S3, the slope is north-facing which may contain more moisture content which further reduces the effective stress due to the increase in pore pressure and may destabilise the slope (figure 4).

\section{Geotechnical aspects for landslide investigation}

\subsection{Field investigation}

Traverse mapping was carried out to collect the dip-strike data (100 data points) along the 


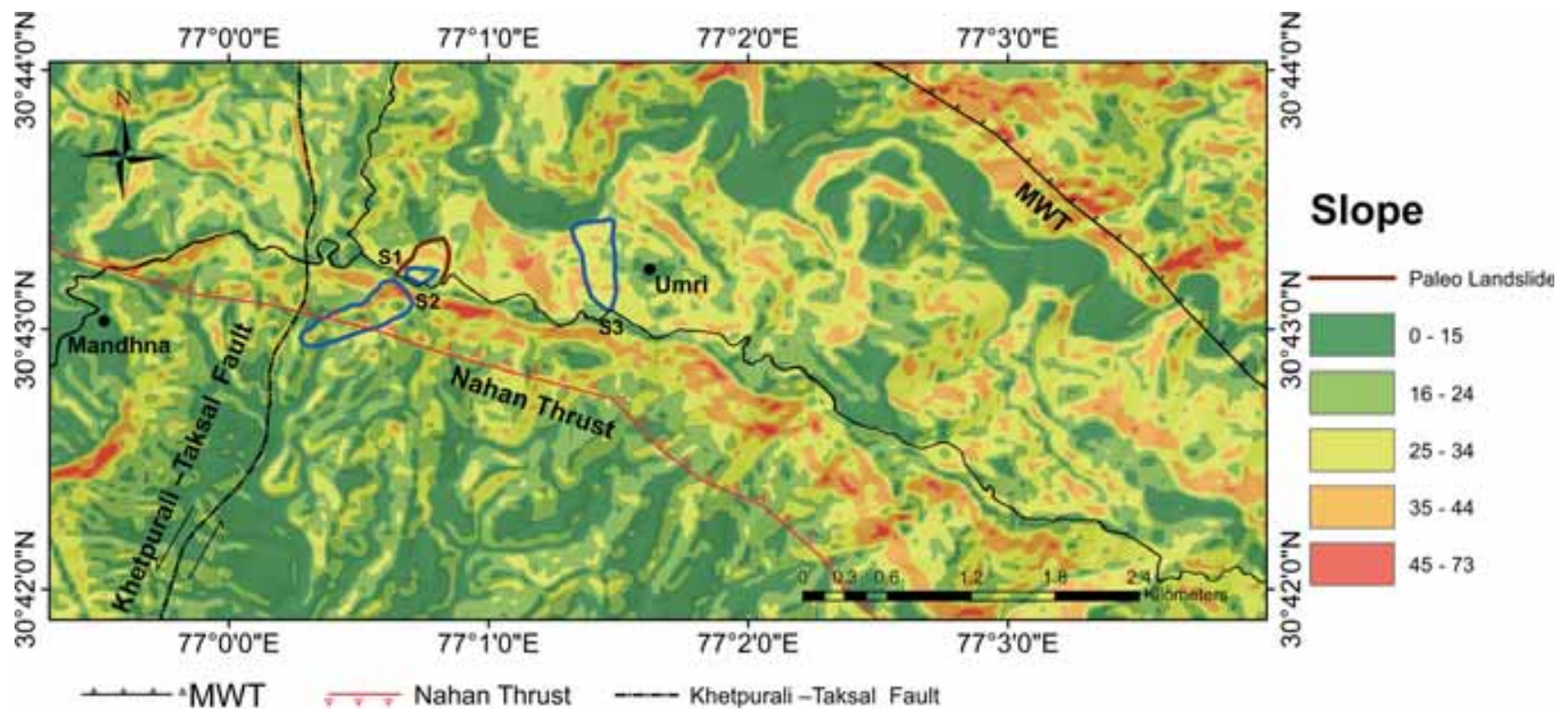

Figure 3. Slope angle of the study area using Bhuvan, Carto DEM. The slope angle varies from 0 to more than $70^{\circ}$.

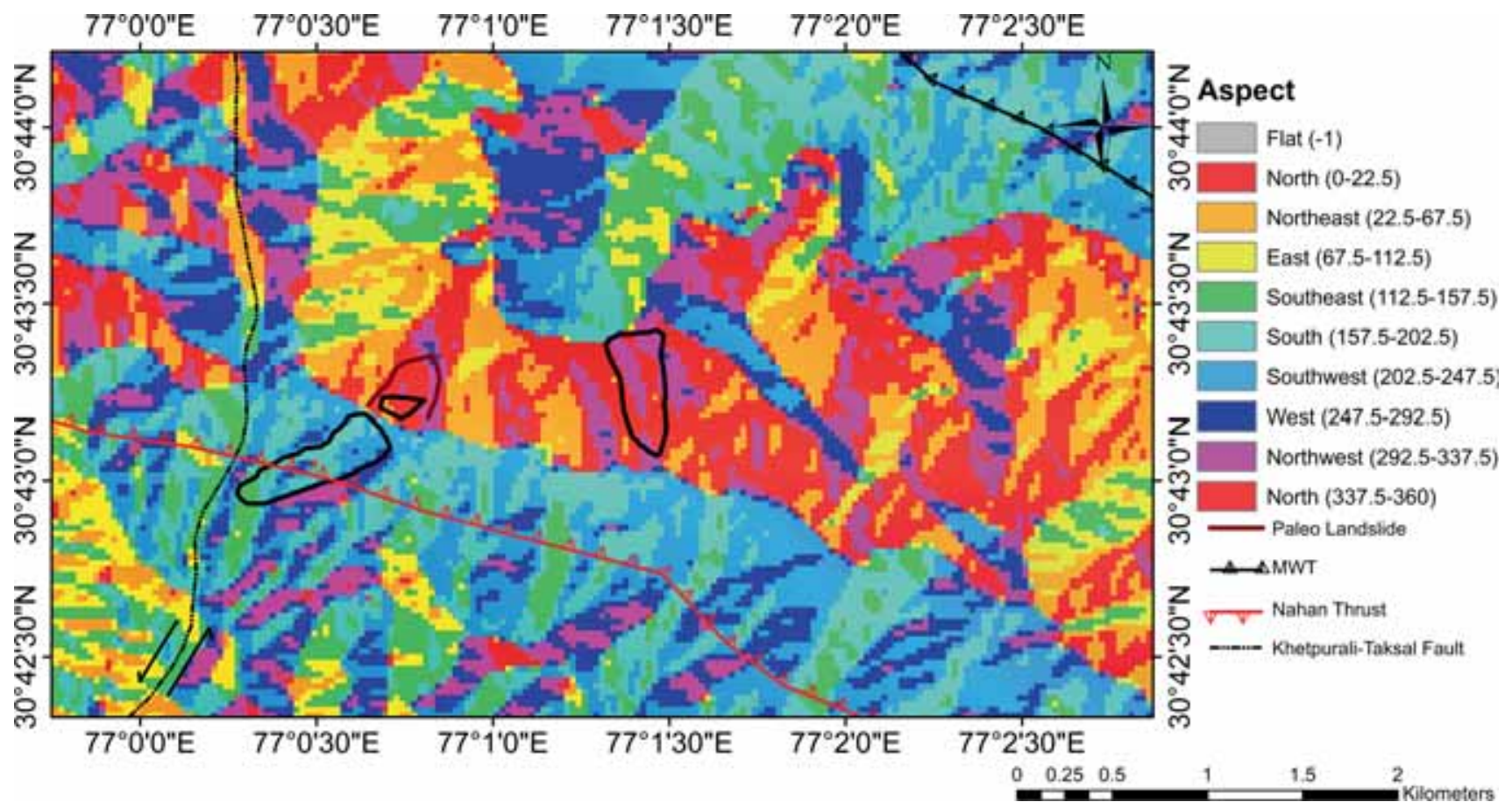

Figure 4. Aspect map of the study area which shows the dip direction of the slopes with respect to the north.

Panchkula-Morni road cut slope covering all three unstable slope sites S1, S2 and S3. The slope at site $\mathrm{S} 1$ is unstable in the NE direction (figures $5 \mathrm{~A}$ and 9A), whereas the slope at site $\mathrm{S} 2$ is unstable in the SW direction opposite to S1. The lithology at sites S1 and S2 which are located on the opposite side of the slope (water divide) mainly consists of the lower Siwalik sandstone unit. At site S3 (Umri landslide), sandstone beds are interbedded with the clay and mud rocks as shown in figure 5(B). The houses near the site $\mathrm{S} 3$ show cracks in the roof and walls due to the movement of basement rocks near the Umri landslide. Four joint sets are identified in the rock mass at site S3. At the crown of the landslide, a tensional crack of thickness $60 \mathrm{~cm}$ is observed due to the circular failure at site S3 as shown in figure $5(\mathrm{C})$. At the Umri landslide, two normal faults (figure 5D and E) are identified with 

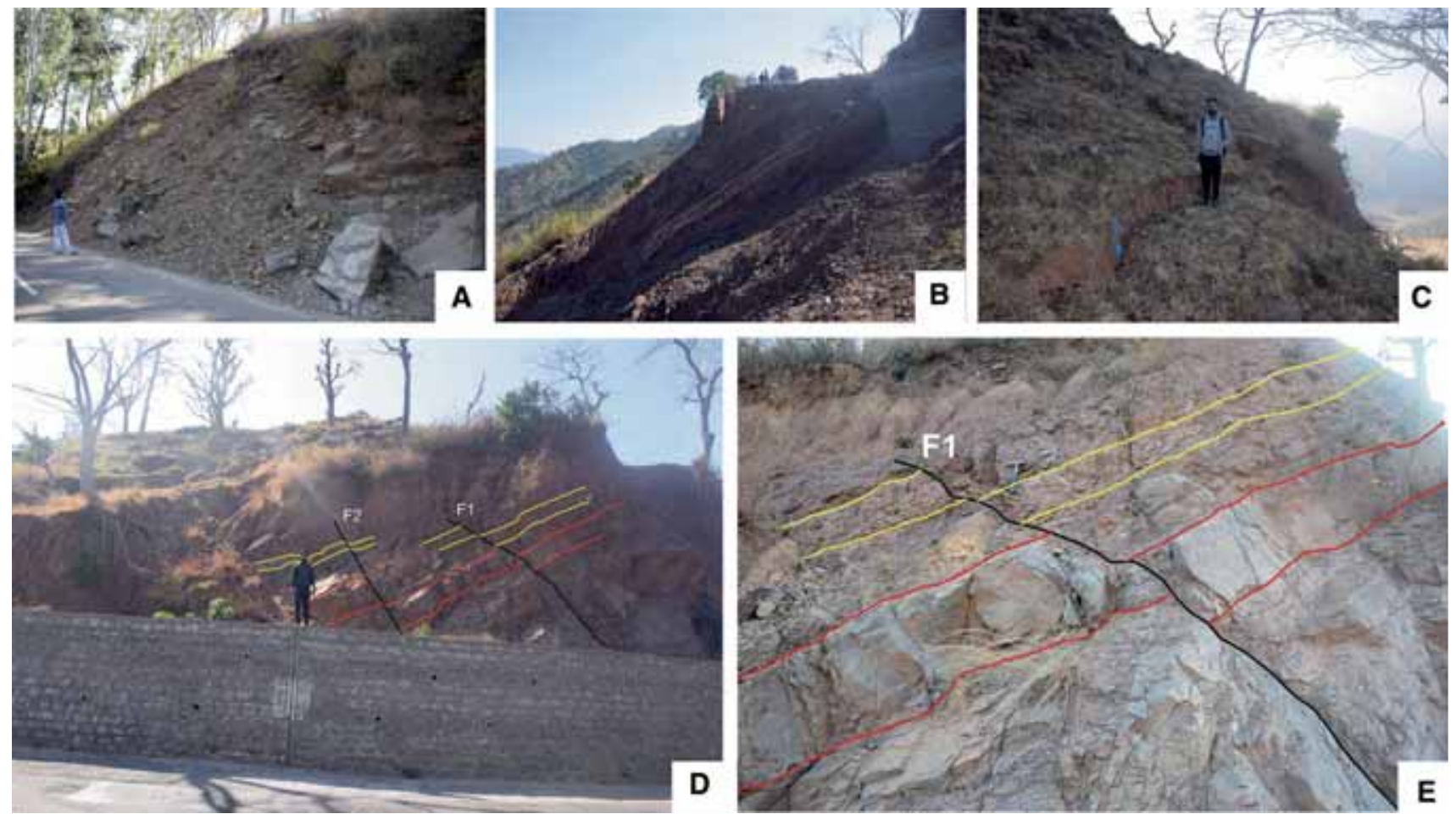

Figure 5. Field photographs: (A) At site S1, unstable road cut slope showing planar failure dominantly composed of sandstone (location figure 1) (B) S3 (Umri landslide) near Umri village, the section is exposed due to landslide showing interbedded sandstone and clay (location figure 1). (C) Tension crack with a thickness of $60 \mathrm{~cm}$ due to failure at site S3. (D) Two faults identified in the field on the road cut slope at site S3. (E) Normal faults with hanging wall moving down relative to the footwall at site S3.

a fault plane dipping at an angle of $55-330^{\circ}$. The main body of the Umri landslide slope is still unstable and damages the road as shown in figure $6(\mathrm{~A}$ and $\mathrm{B})$. Deranged forest and traverse ridges are formed due to the piling up of debris down the slope of the landslide (site S3) as shown in the figure $6(\mathrm{~B})$. The dip-strike data collected during the field study plotted on Stereonet indicates that the regional trend of the lower Siwalik sandstone is due $\mathrm{N} 40^{\circ} \mathrm{E}$ as shown in table 2 and figure 7 . A systematic 3D block model for site S3 (Umri landslide) is constructed which shows different joint sets and the normal fault found in the rock mass and Stereonet depicts the orientation of joint sets and the fault at site S3 (figure 8).

\subsection{Rock quality designation}

RQD is the most commonly used method to characterise the degree of jointing in borehole cores. It was developed by Deere (1963) to provide a quantitative estimate of rock mass quality from drill core logs. It is defined as 'the percentage of intact core pieces longer than $100 \mathrm{~mm}$ in the total length of core'. The core should be at least NX size
(54.7 $\mathrm{mm}$ in diameter) and should be drilled with a double-tube core barrel. The RQD is calculated by the indirect method of volumetric joints count $(\mathrm{Jv})$ developed by Palmstrom (1982). Jv is described as a measure for the number of joints within a unit volume of rock mass defined by

$$
J v=\sum \frac{1}{S i}, \quad i=1, \ldots, j
$$

where $S i$ is the average joint spacing in metres for the $i$ th joint set and $j$ is the total number of joints. For site S1, S2 and S3 using joint spacing, Jv and RQD are calculated as listed in table 3 .

\subsection{Rock mass classification}

Rock mass classification systems are used for various engineering design and stability analyses. The system is developed to understand the field conditions and provide ratings to determine the rock mass, to pre-determine excavations and other processes required for engineering purposes (Aksoy 2008). The objective of rock mass classification is to 

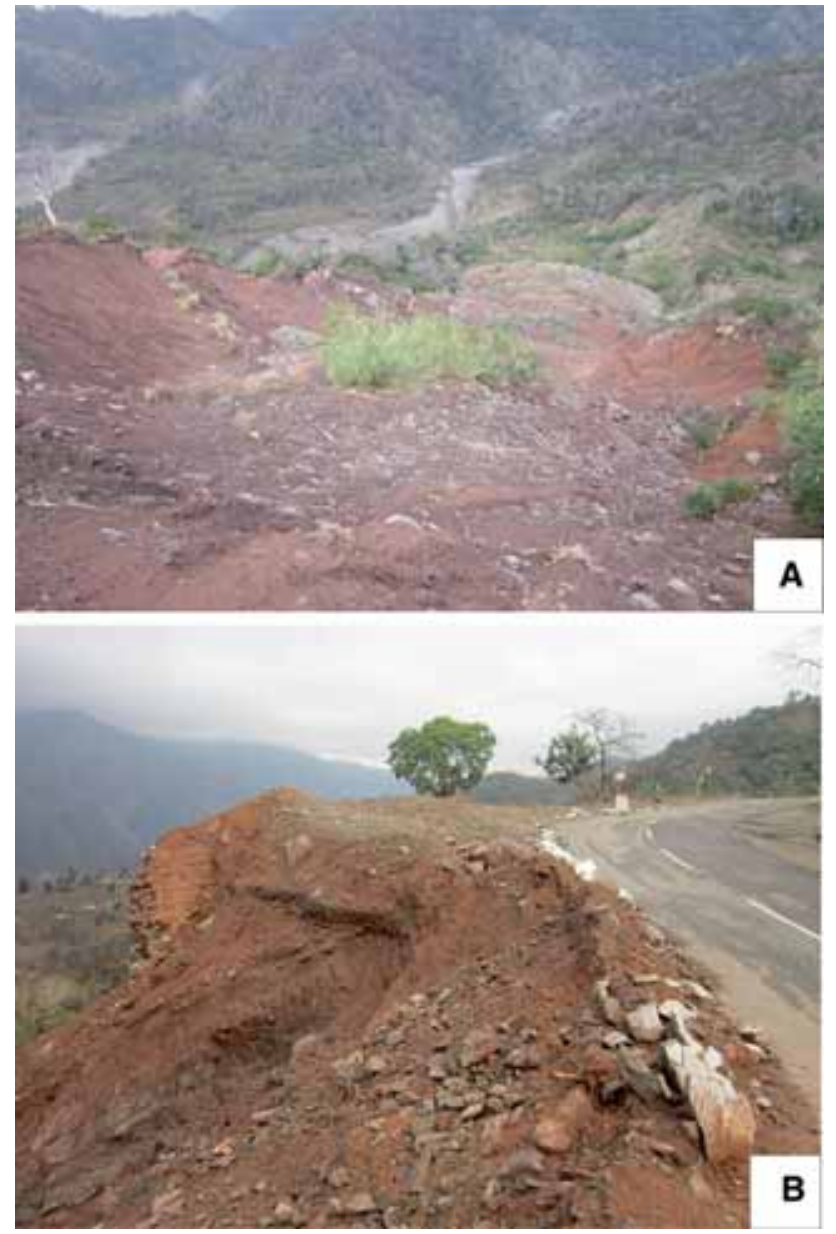

Figure 6. Field photographs of the Umri landslide in Haryana, India. The crown area is still unstable, causing serious damage to road.

Table 2. The average regional trend data of all joints calculated using Stereonet (figure 8) along the Panchkula-Morni road.

\begin{tabular}{lcc}
\hline Joints & $\begin{array}{c}\text { Dip } \\
\text { direction } \\
\text { (deg) }\end{array}$ & $\begin{array}{c}\text { Dip } \\
\text { amount } \\
\text { (deg) }\end{array}$ \\
\hline J1 (bedding) & 39 & 38 \\
J2 & 306 & 74 \\
J3 & 240 & 58 \\
J4 & 159 & 69 \\
\hline
\end{tabular}

understand the intrinsic properties of the rock mass and how other external factors affect its behaviour (Milne et al. 1998).

\subsubsection{Rock mass rating}

The RMR system was first developed by Bieniawski (1973) at the South Africa scientific and

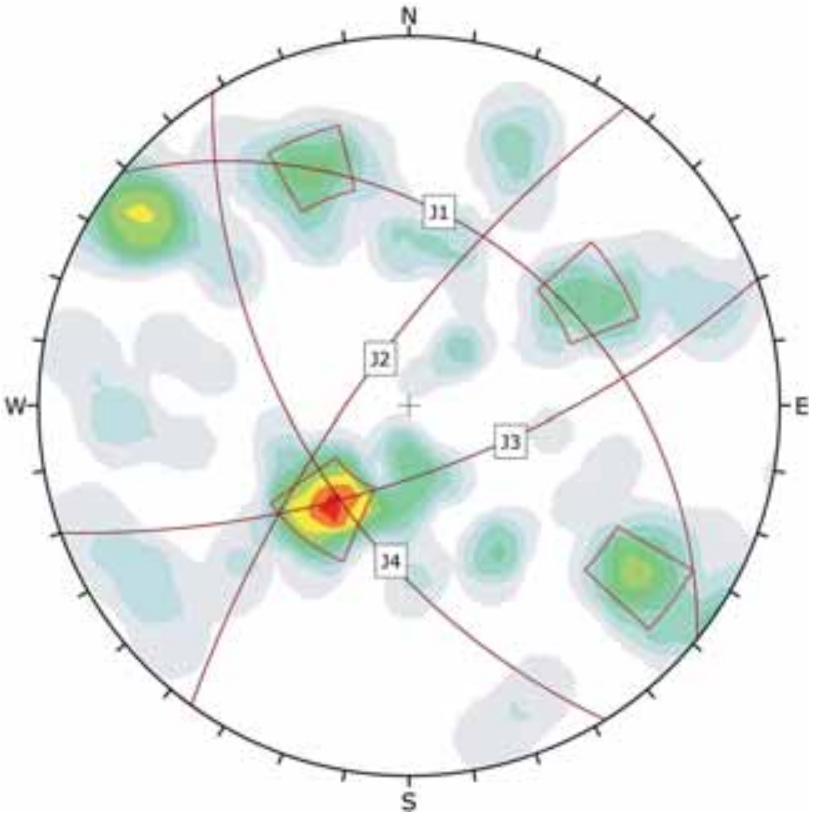

Figure 7. Stereograph with four regional joint sets marked as J1, J2, J3 and J4. J1 is parallel to the bedding plane and its high frequency is represented by poles countoured in red colour.

industrial research, and since its development, it has undergone several improvements (Bieniawski 1974, 1975, 1976). RMR is widely used in engineering purposes like tunnelling, slope stability and dams (Siddique et al. 2017). RMR is calculated on the basis of six parameters (uniaxial compressive strength (UCS), RQD, joint or discontinuity spacing (DS), joint condition, ground water condition and joint orientation). The rating is given to all parameters depending upon their values and all ratings are added to get the RMR of the rock mass. On the basis of the RMR values for a given structure, the rock mass is sorted into five classes: very good $(\mathrm{RMR}=100-81)$, good $(80-61)$, fair $(60$ $41)$, poor (40-21) and very poor $(\mathrm{RMR}<20)$. The RMR values for the slope faces at sites $\mathrm{S} 1, \mathrm{~S} 2$ and S3 are shown in table 5.

The UCS of the intact rock (sandstone) was tested in the Geotechnical Laboratory, Department of Geology, Panjab University, Chandigarh by extracting NX-type cores (approximately $54 \mathrm{~mm}$ diameter) as per the specifications given by the International Society of Rock Mechanics (ISRM 1978). The UCS of the lower Siwalik sandstone tested in the laboratory and has an average value of $37.6 \mathrm{MPa}$ as shown in table 4 and the RMR of the sites S1, S2 and S3 are calculated as shown in table 5 which varies from 31 to 55 . 


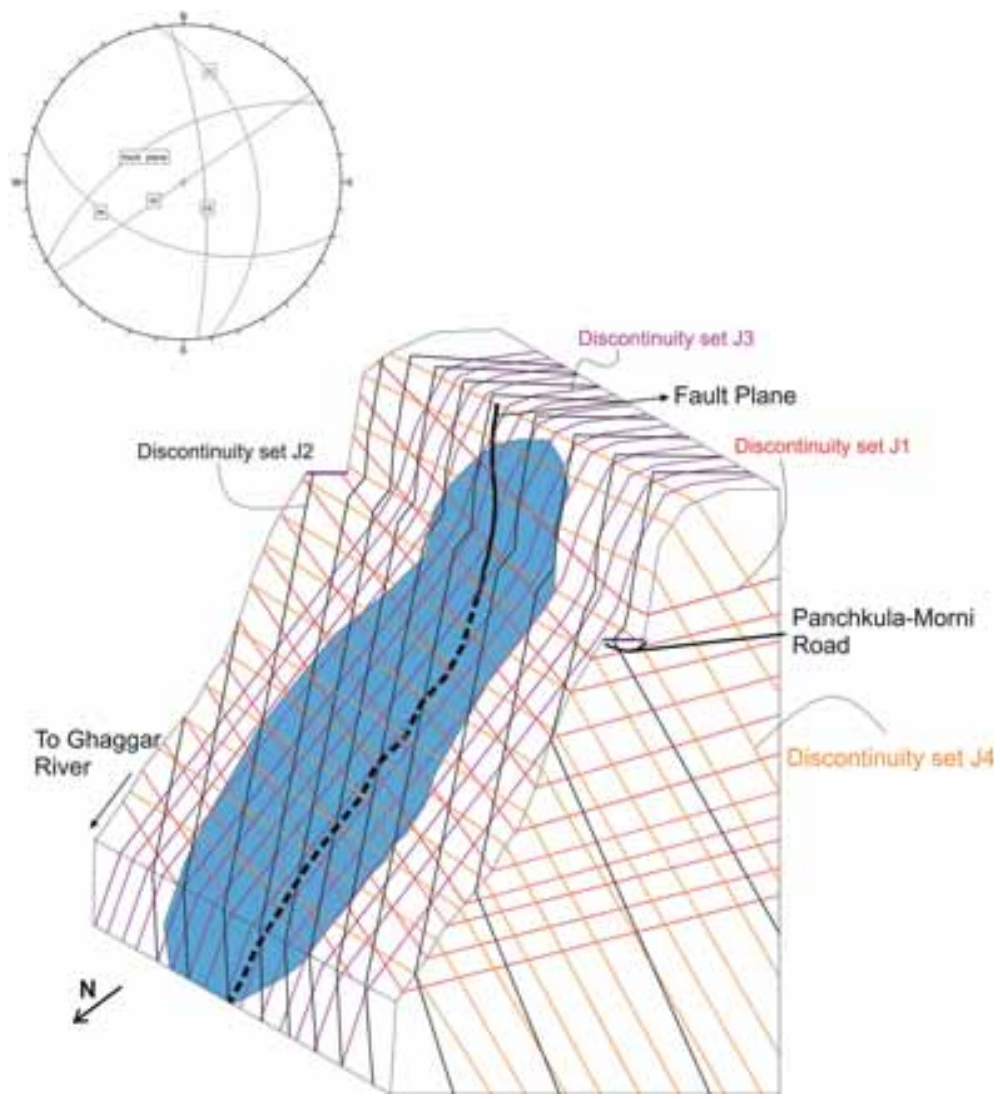

Figure 8. Conceptual three-dimensional-block model of the Umri landslide showing the presence of the discontinuity sets and the tectonic structure that influence the stability of the slope. Stereonet depicts the orientation of the fault and different joint sets at site S3 (not to scale).

Table 3. RQD of the slopes and volumetric joint count (Jv).

\begin{tabular}{lcccccc}
\hline Site & $\mathrm{J} 1(\mathrm{~m})$ & $\mathrm{J} 2(\mathrm{~m})$ & $\mathrm{J} 3(\mathrm{~m})$ & $\mathrm{J} 4(\mathrm{~m})$ & Jv & RQD $(\%)$ \\
\hline S1 & 0.36 & 0.33 & 0.57 & 0.55 & 9.38 & 84 \\
S2 & 0.36 & 0.33 & 0.57 & 0.55 & 9.38 & 84 \\
S3 & 0.70 & 0.70 & 0.45 & 0.50 & 7.07 & 91 \\
\hline
\end{tabular}

Table 4. Uniaxial compressive strength of the intact rock samples collected from the Umri landslide (site S3).

\begin{tabular}{lc}
\hline Sample & UCS (MPa) \\
\hline 1 & 36 \\
2 & 39 \\
3 & 38 \\
Mean & 37.6 \\
\hline
\end{tabular}

\subsubsection{Slope mass rating}

Romana (1985, 1991, 1993, 1995) proposed a classification by considering joint orientation with respect to slope orientation to understand rock stability known as SMR. SMR is a widely used tool to understand the stability in rocky slopes (Siddique et al. 2017). SMR is calculated from Bieniawski's RMR by subtracting adjustment factors of the joint-slope relationship and adding a factor depending on the method of excavation:

$$
\mathrm{SMR}=\mathrm{RMR}_{\text {basics }}+(F 1 \cdot F 2 \cdot F 3)+F 4,
$$

where $\mathrm{RMR}_{\text {basics }}$ is calculated according to Bieniawski (1993) by adding the rating of only five parameters (UCS, RQD, joint or DS, joint condition, ground water condition) and $(F 1, F 2, F 3)$ are adjustment factors related to joint orientation with respect to the slope and $F 4$ is the correction factor for the method of excavation which includes natural slope and cut slope by different 
Table 5. RMR of sites S1, S2 and S3.

\begin{tabular}{|c|c|c|c|c|c|c|c|c|c|c|c|c|c|}
\hline \multirow[b]{2}{*}{ Location } & \multirow{2}{*}{$\begin{array}{l}\text { UCS } \\
(\mathrm{MPa})\end{array}$} & \multirow{2}{*}{$\begin{array}{c}\text { RQD } \\
\% \\
\end{array}$} & \multirow[b]{2}{*}{ DS } & \multicolumn{5}{|c|}{$\mathrm{DC}$} & \multirow[b]{2}{*}{ GW } & \multirow[b]{2}{*}{$\mathrm{RMR}_{\mathrm{B}}$} & \multirow[b]{2}{*}{ AOD } & \multirow[b]{2}{*}{ RMR } & \multirow{2}{*}{$\begin{array}{l}\text { Description } \\
\text { and class }\end{array}$} \\
\hline & & & & $P$ & $S$ & $R$ & $I$ & $W$ & & & & & \\
\hline $\mathrm{S} 1$ & 4 & 17 & 5 & 2 & 1 & 3 & 6 & 3 & 15 & 56 & -25 & 31 & Poor (IV) \\
\hline $\mathrm{S} 2$ & 4 & 17 & 5 & 2 & 1 & 3 & 6 & 3 & 15 & 56 & -25 & 31 & Poor (IV) \\
\hline S3 & 4 & 20 & 10 & 2 & 1 & 3 & 2 & 3 & 15 & 60 & -5 & 55 & Fair (III) \\
\hline
\end{tabular}

UCS: uniaxial compressive strength; RQD: rock quality designation; DS: discontinuity spacing; DC: discontinuity condition; $P$ : persistence; $S$ : separation; $R$ : roughness; $I$ : infilling; $W$ : weathering; GW: ground water; AOD: adjustment factor for the orientation of discontinuity; $\mathrm{RMR}_{\mathrm{B}}=$ rock mass rating basic.

Table 6. SMR for sites S1, S2 and S3 calculated using the CSMR method.

\begin{tabular}{|c|c|c|c|c|c|c|c|c|c|}
\hline $\begin{array}{l}\text { Slope } \\
\text { site }\end{array}$ & $\mathrm{RMR}_{\mathrm{B}}$ & $F 1$ & $F 2$ & $F 3$ & $F 4$ & SMR & Class & Grade & Failure \\
\hline S1 & 56 & 0.94 & 0.87 & -59.04 & 0 & 7.37 & $\mathrm{~V}$ & Very bad & Planar \\
\hline $\mathrm{S} 2$ & 56 & 0.91 & 0.92 & -59.27 & 15 & 21.17 & IV & Bad & Wedge \\
\hline S3 & 60 & 0.17 & 0.83 & -58.94 & 15 & 66.26 & II & Good & Wedge \\
\hline
\end{tabular}

methods. By using the above parameters, SMR is calculated for different types of failure (Siddique et al. 2017). The SMR values for the slope faces at sites S1, S2 and S3 (Umri landslide) are shown in table 6 .

\subsubsection{CSMR}

In 1985, Romana proposed the SMR and suggested the ratings for $F 1, F 2, F 3$ and $F 4$ which are discrete and depend mostly on the judgement of the investigator; this may result in the deviation of the results of SMR values. Later, Tomas and Seron (2007) introduced a new continuous function to get more accurate values and it helps in delineating the boundary values in pre-existing intervals. Equations given by Tomas and Seron (2007) are as follows:

$$
\begin{aligned}
F 1 & =\frac{16}{25}-\frac{3}{500} \arctan \left(\frac{1}{10}|A|-17\right), \\
F 2 & =\frac{9}{16}+\frac{1}{195} \arctan \left(\frac{17}{100} B-5\right), \\
F 3 & =-30+\frac{1}{3} \arctan C, \\
F 3(t) & =\frac{1}{7} \arctan (C-120),
\end{aligned}
$$

where $A$ is $\left|a_{\mathrm{j}}-a_{\mathrm{s}}\right|$ for planar failure, $\left|a_{\mathrm{j}}-a_{\mathrm{s}}-180\right|$ for toppling failure and $\left|a_{\mathrm{i}}-a_{\mathrm{S}}\right|$ for wedge failure.

$B$ is $b_{\mathrm{j}}$ for planar failure and $b_{\mathrm{i}}$ for wedge failure and $F 2$ remains 1 for the toppling mode of failure and $F 3(t)$ is for toppling.
$C$ is $b_{\mathrm{j}}-b_{\mathrm{s}}$ for planar failure, $b_{\mathrm{i}}-b_{\mathrm{s}}$ for wedge failure and $b_{\mathrm{j}}-b_{\mathrm{s}}$ for toppling failure.

Note: The arctan values should be in degrees and as is the dip direction of slope, $a_{\mathrm{j}}$ is the dip direction of the joint, $b_{\mathrm{s}}$ is the dip amount of the slope, $b_{\mathrm{j}}$ is the dip amount of the joint, $a_{\mathrm{i}}$ is the plunge direction of the line formed by the intersection of two joints and $b_{\mathrm{i}}$ is the plunge of line formed by the intersection of two discontinuities.

\subsection{Kinematic analysis}

Kinematic analysis is a method used to analyse the potential for the various modes of rock slope failures (plane, wedge, toppling failures), that occur due to the presence of unfavourably oriented discontinuities and it is also termed as the 'geometry of motion'. Various failures like planar, wedge and toppling can be judged using the parameters such as orientation of discontinuities or joints and internal friction angle of the rock.

\subsubsection{Planar failure}

The plane on which sliding occurs must strike parallel or nearly parallel (within approximately $\pm 20^{\circ}$ ) to the slope face. The sliding plane must daylight in the slope face. The dip of the sliding plane must be greater than the angle of friction and the upper end of the sliding surface either intersects or terminates into a tensional crack. 


\subsubsection{Wedge failure}

The plunge of the line of intersection of discontinuities must be flatter than the dip of the slope face and steeper than the average friction angle of the two slide planes.

\subsubsection{Direct toppling}

Direct toppling occurs when in strong rock individual columns are formed by a set of discontinuities dipping steeply into the face. A second set of widely spaced joints defines the column height (Hudson and Harrison 1997).

RMR can be used to estimate the cohesion and internal friction angle of the rock mass for sites S1, S2 and S3 (Bieniawski 1993). The friction angle of rock mass and dip of the slope face used in the kinematic analysis is shown in table 7 .

\subsection{Sieve analysis}

Sieve analysis is the technique to differentiate the grains on the basis of their size. It was used to separate silt, clay and sand in the soil sample of slope S3 (Umri landslide). First, by weight, $100 \mathrm{~g}$ of the dry soil sample was taken for sieve analysis. After sieving, the independent weight of the soil in each sieve was measured to compare the relative amount of silt, clay/silt and sand in the soil. The sieve analysis data were plotted with size vs. percent finer by weight to prepare the particle size distribution curve (figure 12). The uniformity coefficient $(\mathrm{Cu})$ and coefficient of gradation $(\mathrm{Cc})$ were calculated. If $\mathrm{Cc}$ is between 1 and 3 the soil is well graded, but if $\mathrm{Cc}<1$ soil is poorly graded. Poorly graded is further classified into gap-graded and uniformly graded depending upon grain sizes. Also, it is clearly depicted from the particle size distribution curve that the soil at site S3 is gap-graded because some intermediate sizes are missing. The gap-graded soils generally have excellent drainage

Table 7. Friction angle (Bieniawski 1993) and dip of slope face (DEM; http://bhuvan.nrsc.gov. in).

\begin{tabular}{lcc}
\hline $\begin{array}{l}\text { Slope } \\
\text { site }\end{array}$ & $\begin{array}{c}\text { Angle of } \\
\text { friction } \\
\text { (deg) }\end{array}$ & $\begin{array}{c}\text { Dip of slope } \\
\text { face } \\
\text { (deg) }\end{array}$ \\
\hline S1 & 30 & 60 \\
S2 & 30 & 60 \\
S3 & 35 & 50 \\
\hline
\end{tabular}

quality (permeability coefficient, $K>10^{-3} \mathrm{~cm} / \mathrm{s}$ ) (Pandit et al. 2016). The flowing water gives rise to seepage forces and water pressure which in turn reduce the frictional effect and decreases the instability of the soil:

$$
\begin{aligned}
& \text { Uniformity coefficient }(\mathrm{Cu}) \\
& \quad=D_{60} / D_{10}=0.73 / 0.071=10.28, \\
& \text { Coefficient of gradation }(\mathrm{Cc}) \\
& \quad=D_{30}^{2} / D_{60} * D_{10} \\
& =0.14 * 0.14 / 0.73 * 0.071=0.38 .
\end{aligned}
$$

\section{Factor of safety (FS)}

FS is the most common method of slope design, and it is widely applicable to many types of geological conditions, for both rock and soil. FS is the ratio of resisting and driving forces acting on the slope. For $\mathrm{FS}>1$, the slope is stable; if $\mathrm{FS}<1$, the slope is unstable. A rapid check of the stability of a wedge can be made if the slope is drained and there is zero cohesion on both slide planes $\mathrm{A}$ and $\mathrm{B}$. If the sliding surface is clean and contains no infilling, then the cohesion is likely to be zero. Under these conditions, the FS of the wedge failure (site S2) can be calculated using the equation given by (Hoek et al. 1973)

$$
F=A \tan \phi+B \tan \phi .
$$

The dimensionless factors $A$ and $B$ depend upon the dip amount and dip directions of the two planes which join to form a wedge. The values of these factors can be estimated from the wedge stability charts for friction only. $\phi$ is the friction angle.

The value of $A$ and $B$ estimated from the friction-only stability charts by Hudson and Harrison (1997) and using values given in table 8 is 1.1:

$$
F S=2 * 1.1 \tan 30=1.2 .
$$

Table 8. Wedge stability analysis for friction only (site S2).

\begin{tabular}{lccc}
\hline & $\begin{array}{c}\text { Dip } \\
(\mathrm{deg})\end{array}$ & $\begin{array}{c}\text { Dip direction } \\
(\mathrm{deg})\end{array}$ & $\begin{array}{c}\text { Friction angle } \\
(\mathrm{deg})\end{array}$ \\
\hline Plane A & 70 & 300 & 30 \\
Plane B & 70 & 160 & 30 \\
Differences & 0 & 140 & \\
\hline
\end{tabular}


Therefore, the FS is 1.2 which reveals that the slope at site $\mathrm{S} 2$ is critically stable.

\section{Results and discussion}

The kinematic analysis and geomechanical classifications of the rock mass are very important tools for the investigation of vulnerable slopes. The friction angle of rock mass used in kinematic analysis is estimated from the RMR classification of rock mass (Bieniawski 1993), depending upon their RMR values. The RMR rating is calculated using the method given by Bieniawski (1993) and the SMR rating is calculated by the method given by Romana (1985) and Tomas and Seron (2007).

The kinematic analysis of site S1 shows three modes of failure: planar, wedge and direct toppling (figure 9). In figure 9(B), a pole to joint J1 lies in the shaded region fulfilling the condition of planar failure. The intersection of joint J1 with joints J2 and J3 forms two wedges with the trend of line of intersection being at $\mathrm{N} 15^{\circ} \mathrm{E}$ and $\mathrm{N} 80^{\circ} \mathrm{E}$, respectively, as shown in figure $9(\mathrm{C})$. Blocks formed due to these wedges will slide along the joint $\mathrm{J} 1$ in the NE direction. The line of intersection of joints J2 and $\mathrm{J} 3$ is dipping into the slope which forms the edge of block and the joint J1 acts as a surface for direct toppling in the NE direction as shown in figure $9(\mathrm{D})$. The RMR value at site $\mathrm{S} 1$ is 31 (table 5), representing the poor quality of the rock mass. The SMR (planar) value is 7 at site S1 which lies in class $\mathrm{V}$ (table 6 ) and the slope face is classified as completely unstable. Hence, using kinematic analysis and SMR, the slope face at site $\mathrm{S} 1$ is unstable. Therefore, the instability along the road cut slope at site S1 is dangerous for road transport.
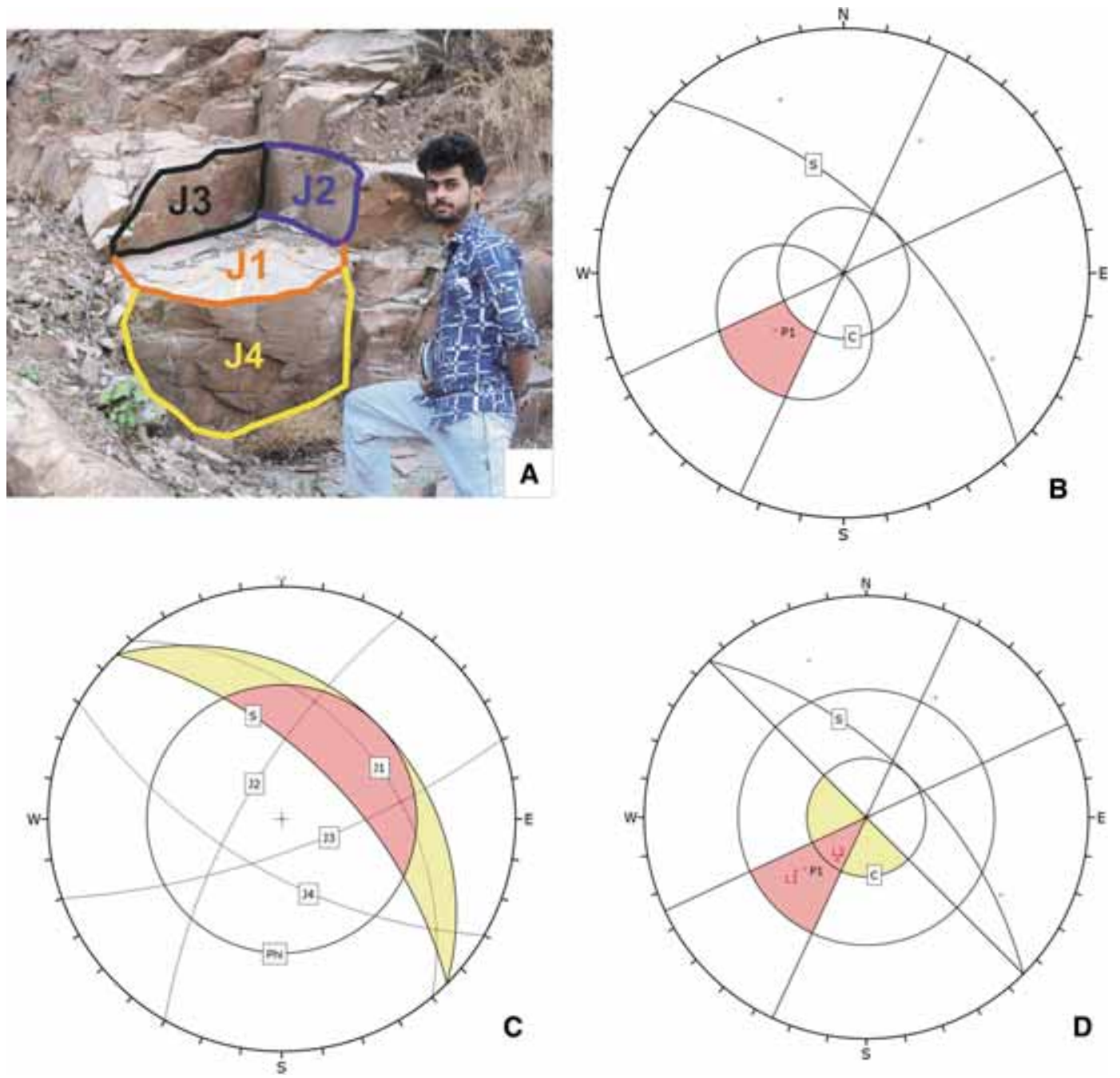

Figure 9. Kinematic analysis of the slope at site $\mathrm{S} 1 ; S=$ slope face; $c=$ cone of friction; $\phi=$ angle of friction; P1 $=$ pole to joint $\mathrm{J} 1 ; \mathrm{L} 1=$ line of the intersection of joint $\mathrm{J} 2$ and $\mathrm{J} 3$; L2 = line of the intersection of joints J3 and J4. 
Furthermore, the kinematic analysis of site S2 (figure 10) clearly shows the formation of a wedge due to the intersection of the two joints J2 and $\mathrm{J} 3$ and the intersection lies in the shaded region. The RMR value is 31 for site S2 (table 5) which represents the poor quality of the rock mass and the SMR (wedge) value is 21 which lies in class IV (table 6). Hence, the slope at site S2 is classified as unstable. The FS calculated using friction-only charts is 1.2 which defines the slope as critically stable. A little increase in the disturbing factors like

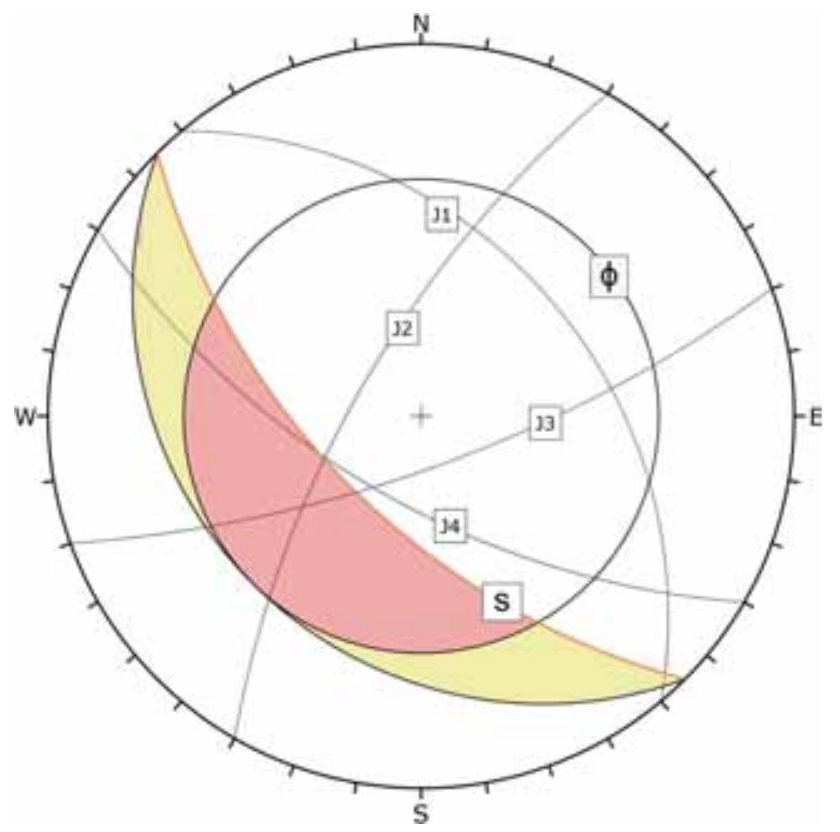

Figure 10. Kinematic analysis of the slope at site S2; $\phi=$ angle of friction; $S=$ slope face. earthquake vibrations as this region is highly active and pore water pressure due to rainfall can easily destabilise the slope. Due to the Nahan thrust, the zone is highly fractured and damaged, the rock mass loses its stability because of the daylighting of the structural features and rainfall. Therefore, failure at sites S1 and S2 is mainly controlled by the joint sets and the slope angle.

The kinematic analysis of site S3 (figure 11) shows the mode of wedge failure, the wedge due to the intersection of the fault plane and joint J3 dipping out of the slope. The wedges formed due to the intersection of the fault plane and J1 (parallel to bedding) and the intersection of joints $\mathrm{J} 1$ and $\mathrm{J} 2$ also lie near the critical zone. The RMR value is 55 (table 5) for site S3 which represents the fair quality of the rock mass and the SMR (wedge) of joints is 66 for site S3 which lies in class II (table 6). Hence, the slope is classified as a stable slope with failure in some blocks. This points towards the fact that the rock mass instability at site S3 is governed by other factors. First, the wedge formed by the fault plane and the joint J1 as shown in kinematic analysis (figure 11). The normal faulting in the slope decreases the quality of the rock mass and the damage caused favours the instability. In addition, the fault plane also acts as a pathway for the flow of water because of high persistence than joints. The analysis of the soil samples as shown in figure 12 from site S3 (Umri landslide) shows that the soil is dominantly composed of unconsolidated sand. The cohesion of unconsolidated sand material is generally taken as zero, so the only resisting force left is friction. The percolation of the water
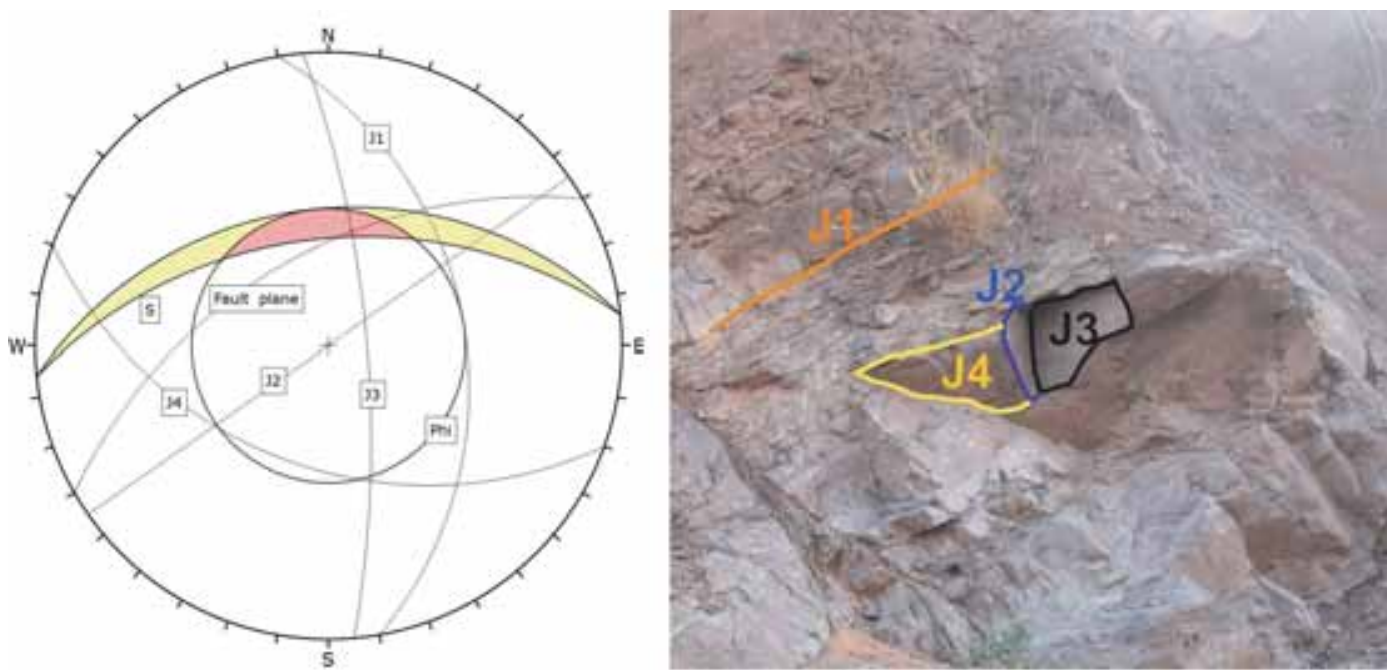

Figure 11. Kinematic analysis of the slope at site $\mathrm{S} 3 ; \phi=$ angle of friction; $S=$ slope face. 


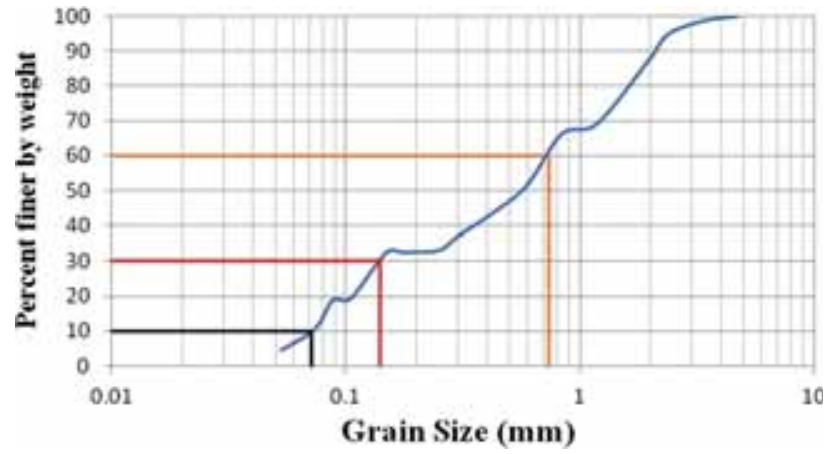

Figure 12. Grain size distribution curve for the soil sample collected from site S3 (Umri landslide).

into the rock mass and gap-graded soil decreases the effective stress which in turn reduces the effect of friction. Therefore, the Umri landslide at site S3 is mainly controlled by structural discontinuities including joints and faults and interbedded soil layers between the sandstone units.

\section{Conclusions}

The rocks forming a slope along the Nahan salient are continuously deforming due to the movement along the MBF and the Nahan thrust. Slope stability assessment was conducted along the Panchkula-Morni road passing through the ridge of the lower Siwalik rocks. The RMR, SMR and kinematic analysis were carried out to investigate the vulnerable slopes. The slopes at sites S1 and S2 are found to be unstable because of the higher slope angle and damage to the rock mass because the region is near the Nahan thrust. With time, the ridge (water divide) between sites $\mathrm{S} 1$ and $\mathrm{S} 2$ will slide and merge together cutting the PanchkulaMorni road. The slope at site S3 has high RMR and SMR values but it is unstable. The instability here is governed by the wedges formed by the intersection of fault planes with joint sets, also, due to the intercalation of sandstone with clay and sand, because during the monsoon, the heavy rainfall decreases the frictional effect of the soil, which results in the instability of the slope. As the failure mechanics at site S3 is complex, a proper numerical modelling technique will be carried out in the future to gain some insight into the causes. All slopes at sites S1, S2 and S3 are vulnerable to road transport and traffic at the slope at site S3 (Umri landslide) is particularly affecting the houses built on the ridge.

\section{Acknowledgements}

The authors express their sincere acknowledgements to the Chairperson, Centre of Advanced Study in Geology, Panjab University, Chandigarh for providing the necessary laboratory and other departmental facilities. They also like to thank $\mathrm{Mr}$ Neeraj Kumar, Mr Gurvinder Singh, Mr Shivam Chawla who helped with obtaining field data, and Dr Girish Chander Kothyari, Institute of Seismological Research, Gandhinagar for the valuable suggestions for improving the manuscript.

\section{References}

Agliardi F, Crosta G B and Zanchi A 2001 Structural constraints on deep-seated slope deformation kinematics; Eng. Geol. 59 83-102.

Aksoy C O 2008 Review of rock mass rating classification: Historical developments, applications and restrictions; J. Min. Sci. 44(1) 51-63.

Ambrosi C and Crosta G B 2006 Large sackung along major tectonic features in the central Italian Alps; Eng. Geol. 83 183-200.

Arora S and Malik J N 2017 A new strike slip fault identified in the foothills of northwest Himalayas around Chandigarh; In: National workshop on Indian Siwaliks: Recent advances and future Research, GSI, Lucknow, pp. 148152.

Auden J B 1934 The geology of the Krol belt; Geol. Surv. India Recs. 67 357-454.

Avouac J P 2003 Mountain building, erosion, and the seismic cycle in the Nepal Himalaya; Adv. Geophys. 46 1-80.

Bali R, Bhattacharya A R and Singh T N 2009 Active tectonics in the outer Himalaya: Dating a landslide event in the Kumaun sector; J. Earth Sci. 6 276-288.

Bergbauer S and Pollard D D 2004 A new conceptual fold-fracture model including prefolding joints, based on the emigrant gap anticline, Wyoming; Geol. Soc. Am. Bull. 116 294-307.

Bettinelli P, Avouac J P, Flouzat M, Jouanne F, Bollinger L, Willis P and Chitrakar G R 2006 Plate motion of India and interseismic strain in the Nepal Himalaya from GPS and DORIS measurements; J. Geodesy. 80 567-589.

Bhambri R, Mehta M, Singh S, Jayangondaperumal R, Gupta A K and Srivastava P 2017 Landslide inventory and damage assessment in the Bhagirathi Valley, Uttarakhand, during June 2013 flood; Him. Geol. 38(2) 193-205.

Bieniawski Z T 1973 Engineering classification of jointed rock masses; Civil Eng. South. Afr. 15 335-344.

Bieniawski Z T 1974 Geomechanics classification in rock masses and its application in tunnelling; In: Advances in rock mechanics, Proceedings of 3rd congress of ISRM, National Academy of Sciences, Washington DC, Vol. 2(A), pp. 27-32.

Bieniawski Z T 1975 Case studies: Prediction of rock mass behaviour by geomechanics classification; In: Proceedings of 2nd Australia-New Zealand conference geomechanics, Brisbane, pp. 36-41. 
Bieniawski Z T 1976 Rock mass classifications in engineering; In: Proceedings of the symposium on exploration rock engineering, Johannesberg, pp. 97-106.

Bieniawski Z T 1993 Classification of rock masses for engineering: The RMR system and future trends; In: Comprehensive rock engineering (ed.) Hudson J A, Pergamon Press, Oxford, New York, Vol. 3, pp. 553-573.

Brideau M A and Stead D 2009 The role of tectonic damage and brittle rock fracture in the development of large rock slope failures; Geomorphology 103 30-49.

Chauhana S, Sharma M, Arora M K and Gupta N K 2010 Landslide susceptibility zonation through ratings derived from artificial neural network; Int. J. Appl. Earth Obs. 12 340-350.

Deere D U 1963 Technical description of rock cores for engineering purposes; Rock. Mech. Eng. Geol. 1(1) 16-22.

Hoek E, Bray J W and Boyd J M 1973 The stability of a rock slope containing a wedge resting on two intersecting discontinuities; Quart. J. Eng. Geol. Hydrogeol. 6 1-55.

Hudson J A and Harrison J P 1997 Engineering rock mechanics: An introduction to principles (2nd edn); The Boulevard, Langford Lane Kidlington, Oxford, UK, pp. 156-158.

ISRM 1978 Suggested methods for determining the uniaxial compressive strength and deformability of rock materials; Int. J. Rock. Mech. Min. 16 135-140.

Jackson J 2002 Landslides and landscape evolution in the Rocky Mountains and adjacent Foothills area, Southwestern Alberta, Canada; Rev. Eng. Geol. 15 325-344.

Jade S, Shrungeshwara T S, Kumar K, Choudhury P, Dumka R K and Bhu H 2017 India plate angular velocity and contemporary deformation rates from continuous GPS measurements from 1996 to 2015; Sci. Rep-UK $\mathbf{7 ( 1 )}$ 11439.

Jayangondaperumal R, Thakur V C, Joevivek V, Rao P S and Gupta A K 2018 Active tectonics of Kumaun and Garhwal Himalaya; Nat. Hazards Springer, Berlin.

Kothyari G C, Pant P D, Moulishree J, Khayingshing L and Malik J N 2010 Active faulting and deformation of quaternary landform Sub-Himalaya, India; Geochronometria 37 63-71.

Kothyari G C, Pant P D and Luirei K 2012 Landslides and neotectonic activities in the main boundary thrust (MBT) zone: Southeastern Kumaun, Uttarakhand; J. Geol. Soc. India 40 101-110.

Krishnan M S 2009 Geology of India and Burma (6th edn); The Madras Law Journal office, Madras, India.

Kumar R and Tandon S K 1985 Sedimentology of plio-pleistocene late orogenic deposits associated with intraplate subduction - The Upper Siwalik subgroup of a part of Panjab sub-Himalaya, India; Sediment. Geol. 42 $105-158$

Kumar S, Wesnousky S, Rockwell G T K, Briggs R W, Thakur V C and Jayangondaperumal R 2006 Paleoseismic evidence of great surface rupture earthquakes along the Indian Himalaya; J. Geophys. Res. 111 1-19.

Kumar M, Rana S, Pant P D and Patel R C 2017a Slope stability analysis of Balia Nala landslide, Kumaun Lesser Himalaya, Nainital, Uttarakhand, India; J. Rock Mech. Geotech. Eng. 9 150-158.

Kumar A, Asthana A K L, Singh R, Priyanka, Jayangondaperumal R, Gupta A K and Bhakuni S S 2017b
Assessment of landslide hazards induced by extreme rainfall event in Jammu and Kashmir Himalaya, Northwest India; Geomorphology 284 72-87.

Larson K M, Bürgmann R, Bilham R and Freymueller J T 1999 Kinematics of the India-Eurasia collision zone from GPS measurements; J. Geophys. Res. 104, https://doi. org/10.1029/1998JB900043.

Lave J and Avouac J P 2000 Active folding of fluvial terraces across the Siwalik Hills, Himalayas of central Nepal; J. Geophys. Res. 105 5735-5770.

Lee S and Nguyen T D 2005 Probabilistic landslide susceptibility mapping in the Lai Chau province of Vietnam: Focus on the relationship between tectonic fractures and landslides; Environ. Geol. 48 778-787.

Malik J N and Mathew G 2005 Evidence of paleoearthquakes from trench investigations across Pinjore Garden fault in Pinjore Dun, NW Himalaya; J. Earth Syst. Sci. $114387-$ 400.

Malik J N and Nakata T 2003 Active faults and related late Quaternary deformation along the Northwestern Himalayan Frontal Zone, India; Ann. Phys. 46 917-935.

Malik J N, Nakata T, Philip G and Virdi N S 2003 Preliminary observations from trench near Chandigarh, NW Himalaya and their bearing on active faulting; Curr. Sci. 85 1793-1799.

Mathew J, Jha V K and Rabat G S 2005 Application of binary logistic regression analysis and its validation for landslide hazard mapping in part of Narwhal Himalaya, India; Int. J. Remote Sens. 28 2257-2275.

Medlicott H B 1864 On the geological structure and relations of the southern portion of the Himalayan ranges between rivers Ganges and the Ravi; Mem. Geol. Surv. India 3(2) 122 .

Meunier P, Hovius N and Haines J A 2007 Regional patterns of earthquake-triggered landslides and their relation to ground motion; Geophys. Res. Lett. 34 L20408.

Milne D, Hadjigeorgiou J and Pakalnis R 1998 Rock mass characterization for underground hard rock mines; Tunn. Undergr. Sp. Tech. 13(4) 383-391.

Nakata T 1989 Active faults of Himalaya, India and Nepal; Geol. Soc. Am. Spec. Paper 232 243-264.

Newmark N M 1965 Effects of earthquakes on dams and embankments; Geotechnique 15(2) 139-160.

Palmstrom 1982 The volumetric joint count - A useful and simple measure of the degree of jointing; In: Proceedings $I V$ international congress IAEG, New Delhi, pp. 221-228.

Pandit K, Sarkar S, Samanta M and Sharma M 2016 Stability analysis and design of slope reinforcement techniques for a Himalayan landslide; RARE 97-104, https://doi. org/10.2991/rare-16.2016.16.

Paul S K, Bartarya S K, Rautela P and Mahajan A K 2000 Catastrophic mass movement of 1998 monsoons at Malpa in Kali Valley, Kumaun Himalaya, India; Geomorphology 35 169-180.

Philip G, Suresh N and Bhakuni S S 2014 Active tectonics in the northwestern outer Himalaya: Evidence of largemagnitude palaeoearthquakes in Pinjaur Dun and the Frontal Himalaya; Curr. Sci. 106 2-25.

Pilgrim G E and West WD 1928 Structure and correlation of Simla Rocks; Mem. Geol. Surv. India $\mathbf{5 3}$ 140 . 
Pradhan S P, Vishal V and Singh T N 2011 Stability of slope in an open cast mine in Jharia coalfield, India - a slope mass rating approach; Min. Eng. J. 12(10) 36-40.

Ray P K C, Parvaiz I, Jayangondaperumal R, Thakur V C, Dadhwal V K and Bhat F A 2009 Analysis of seismicity-induced landslides due to the 8 October 2005 earthquake in Kashmir Himalaya; Curr. Sci. 97(12) 17421751.

Romana M 1985 New adjustment ratings for application of Bieniawski classification to slopes; In: ISRM, Zacatecas, pp. 49-53.

Romana M 1991 SMR classification; In: Proceedings of the 7 th congress on rock mechanics 2, ISRM, Aachen, Germany, Balkema, Rotterdam, pp. 955-960.

Romana M 1993 A geomechanics classification for slopes: Slope mass rating; In: Comprehensive rock engineering (ed.) Hudson J, Pergamon Publ., Vol. 3, pp. 575600 .

Romana M 1995 The geomechanics classification SMR for slope correction; In: Proceedings of the 8th international ISRM congress, pp. 1085-1092.

Sah N, Kumar M, Upadhyay R and Dutt S 2018 Hill slope instability of Nainital City, Kumaun Lesser Himalaya, Uttarakhand, India; J. Rock Mech. Geotech. Eng. 10280 289.

Sarkar K, Singh A K, Niyogi A, Behera K, Verma A K and Singh T N 2016 The assessment of slope stability along NH-22 in Rampur-Jhakri area, Himachal Pradesh; J. Geol. Soc. India 88 387-393.

Shipton Z K and Cowie P A 2001 Damage zone and slip surface evolution over micro-meter to $\mathrm{Km}$ scales in high-porosity Navajo Sandstone, Utah; J. Struct. Geol. 23 1825-1844.

Shipton Z K and Cowie P A 2003 A conceptual model for the origin of the fault damage zone structures in high-porosity sandstone; J. Struct. Geol. 25 333-344.

Siddique T, Pradhan S P, Vishal V, Monda E and Singh T N 2017 Stability assessment of Himalayan road cut slopes along national highway 58, India; Env. Earth Sci. 76(759) $1-18$.

Singh P K, Singh K K and Singh T N 2017 Slope failure in stratified rocks: A case from NW Himalaya, India; Landslides 14 1319-1331.

Sinvhal H, Agrawal P N, King G C P and Gaur V K 1973 Interpretation of measured movement at a Himalayan (Nahan) thrust; Geophys. J. Roy. Astron. Soc. 34 203210.

Stead D and Wolter A 2015 A critical review of rock slope failure mechanisms: The importance of structural geology; J. Struct. Geol. 74 1-23.

Thakur V C, Jayangondaperumal $\mathrm{R}$ and Malik M A 2010 Redefining Medlicott-Wadia's main boundary fault from Jhelum to Yamuna: An active fault strand of the main boundary thrust in northwest Himalaya; Tectonophys. 489 29-42.

Tomas R and Seron J B 2007 Modification of slope mass rating (SMR) by continuous functions; Int. J. Rock Mech. Min. Sci. 7 1062-1069.

Umrao R K, Singh R, Ahmad M and Singh T N 2011 Stability analysis of cut slopes using continuous slope mass rating and kinematic analysis in Rudraprayag district, Uttarakhand; Geomaterials 1 79-87. 